\title{
Response to an ozone gradient of growth and enzymes implicated in tolerance to oxidative stress in Acer saccharum (Marsh.) seedlings
}

\author{
Catherine GAUCHER ${ }^{\mathrm{a}, \mathrm{b} *}$, Nadine COSTANZO $^{\mathrm{c}}$, Paul WIDDEN $^{\mathrm{c}}$, Jean Pierre RENAUD ${ }^{\mathrm{d}}$, \\ Pierre DIZENGREMEL $^{\mathrm{b}}$, Yves MAUFFETTE ${ }^{\mathrm{a}}$, Normand CHEVRIER $^{\mathrm{a}}$ \\ a GREFi, Département des Sciences Biologiques, Université du Québec à Montréal, C.P. 8888, Succ centre-ville, Montréal, Canada H3C 3P8 \\ ${ }^{\mathrm{b}}$ Écologie et Écophysiologie Forestières, UMR 1137 INRA-UHP Nancy 1, BP 239, 54506 Vandoeuvre, France \\ ${ }^{\mathrm{c}}$ Department of Biology, Concordia University, 1455 West, de Maisonneuve, Montréal, Canada H3G 1M8 \\ ${ }^{\mathrm{d}}$ Centre de recherches Acéricoles-MAPAQ, 1140 rue Taillon, St Foy, Canada G1N 3T9
}

(Received 3 June 2005; accepted 12 October 2005)

\begin{abstract}
Two-year-old sugar maple (Acer saccharum Marsh.) seedlings were exposed in open top chambers to an extensive gradient of $\mathrm{O}_{3}(0$ to $300 \mathrm{~nL} . \mathrm{L}^{-1}$ ) during 85 days under two light environments (20\% and $80 \%$ of full sun at noon on a sunny day). The growth of truncated seedlings (with one flush of leaves) and episodic seedlings (with two flushes) was decreased as $\mathrm{O}_{3}$ increased, especially the growth of the second flush which developed under the oxidative treatment. Visible leaf injuries developed during the season under high $\mathrm{O}_{3}$ concentrations. Survivalist growth strategy of sugar maple, as seen by the root/shoot ratio, together with the enzymatic stimulations of glucose 6-phosphate dehydrogenase, phosphoenolpyruvate carboxylase and glutathione reductase allowed the seedlings to tolerate the $\mathrm{O}_{3}$ doses. However, at the end of the season, the cumulative oxidative stress in the second flush of the episodic seedlings exposed to concentrations over $150 \mathrm{~nL} \cdot \mathrm{L}^{-1} \mathrm{O}_{3}$ was too large and exceeded the capacity of seedlings for detoxification and repair.
\end{abstract}

carboxylation / detoxification / growth / oxidative stress / sugar maple seedlings

Résumé - Réponse de la croissance et des enzymes impliquées dans la tolérance au stress oxydatif chez des semis d'érable à sucre Acer saccharum (Marsh.) exposés à un gradient d'ozone. Des semis d'érable à sucre (Acer saccharum Marsh.) de deux ans sont exposés en chambre à ciel ouvert à un large gradient d' $\mathrm{O}_{3}\left(0\right.$ to $\left.300 \mathrm{~nL} . \mathrm{L}^{-1}\right)$ pendant 85 jours sous deux environnements lumineux $(20$ ou $80 \%$ de plein soleil, journée ensoleillée à midi). Avec l'augmentation des concentrations $\mathrm{d}^{\prime} \mathrm{O}_{3}$, on observe une réduction de la croissance des semis ayant un ou deux flushs de feuilles. La réduction de croissance est particulièrement importante pour le deuxième flush de feuilles qui se développe pendant le traitement. Des dommages foliaires apparaissent durant la saison et sous fortes concentrations d' $\mathrm{O}_{3}$. La stratégie de croissance de survie de l'érable à sucre, montré par le rapport racine/tige, de même que les stimulations enzymatiques de la glucose 6-phosphate déhydrogenase, la phosphoénolpyruvate carboxylase et la glutathion réductase permettent une tolérance aux doses d' $\mathrm{O}_{3}$ reçues. Cependant, à la fin de la saison, le stress oxydatif cumulatif dans le deuxième flush des semis exposés à des concentrations d' $\mathrm{O}_{3}$ supérieures à $150 \mathrm{~nL} \cdot \mathrm{L}^{-1}$ est trop fort et excède la capacité de détoxification et réparation des semis.

carboxylation / detoxification / croissance / stress oxydatif / érable à sucre

\section{INTRODUCTION}

Tropospheric ozone is one of the most damaging phytotoxic pollutants [24], and annual biomass losses of forest species can reach $33 \%$ depending on the species and the $\mathrm{O}_{3}$ concentration $[20] . \mathrm{O}_{3}$ is formed by the photochemical reaction between anthropogenic and biogenic nitrogen oxides (NOx), and volatile organic compounds (VOCs) in polluted air masses. In contrast to other gaseous anthropogenic pollutants such as $\mathrm{SO}_{2}$, tropospheric $\mathrm{O}_{3}$ concentration is increasing, probably due to the increase in the levels of $\mathrm{NO}_{x}$ and VOC emissions [21]. Increase in global tropospheric $\mathrm{O}_{3}$ concentration during the 21 st century was projected by a range of global emission scenarios studied by the IPCC 2001 assessment. In the northern hemisphere, near-surface $\mathrm{O}_{3}$ concentrations are estimated to be increase by about 5 ppb by 2030 and about -4 to over $20 \mathrm{ppb}$ by 2100 , depending on the scenarios [40].

\footnotetext{
*Corresponding author: gaucherc@sympatico.ca
}

Over the last several decades, surface $\mathrm{O}_{3}$ concentrations have been closely monitored in North America by the US Environmental Protection Agency and Environment Canada. The Windsor-Québec region (along the St-Laurence River, Québec, Canada) receives high $\mathrm{O}_{3}$ concentrations from the large industrial and urban regions of the Great Lakes [15]. Several studies have already reported that during the summer, hourly ozone episodes frequently reach $150 \mathrm{~nL} . \mathrm{L}^{-1}$, with maximum values of $200 \mathrm{~nL} . \mathrm{L}^{-1}[15,44,55]$.

Sugar maple (Acer saccharum Marsh.) is found extensively in the Windsor-Québec region and is of major economic importance for the production of timber and sap. It is a shade tolerant, slow growing species [3]. Mature sugar maple trees have been described as a fixed growth species but young and vigorous sugar maple seedlings may have an episodic growth strategy with production of a second flush of leaves $[6,18]$.

Following management of sugar maple stands, sugar maple seedlings may be exposed to contrasting light regimes [54]. In 
plantations, seedlings can be exposed to high irradiance levels [57, 59]. Asthon et al. [1] have reported that the leaves of young maple seedlings have a great capacity to adapt to different irradiance environments. Topa et al. [52] reported that leaves grown in shade show a greater susceptibility to $\mathrm{O}_{3}$ than leaves grown in higher light environments, which is mainly due to the structural differences of the sun and shade leaves $[2,58]$.

Several studies have shown that sugar maple can be affected by $\mathrm{O}_{3}[7,26,51,52]$, although it has been classified as a tolerant species to $\mathrm{O}_{3}[30,35,41]$. No significant effect on growth was observed in sugar maple seedlings after an exposure to 2 times ambient $\mathrm{O}_{3}$ over two growing seasons (seasonal 24-h mean in air-ambient was 31 ppb $\mathrm{O}_{3}$ and 66 ppb $\mathrm{O}_{3}$ in 1990 and 1991 respectively; [42]). Similarly, Laurence et al. [30] found that gas exchange parameters were not affected by $\mathrm{O}_{3}$ after an exposure to 2 times ambient concentration during three growing seasons. However, decreases in biomass accumulation, photosynthetic rate and Rubisco content have been observed in response to higher $\mathrm{O}_{3}$ concentrations $\left(200 \mathrm{~nL} . \mathrm{L}^{-1}\right.$ during 61 days, [16]).

The increased activity of the ascorbate-glutathione detoxication pathway and an increased concentration of antioxidants contribute to the scavenging of toxic oxygen species derived from ozone [14, 36, 37]. Catabolic pathways such as dark respiration, glycolysis and the pentose phosphate pathway have been reported to show increased activity under oxidative stress in some tree species $[9,10,12,16,45]$.

We still lack knowledge on the tolerance of sugar maple to $\mathrm{O}_{3}$ and on the detoxification and repair capacities of sugar maple seedlings under an extensive gradient of $\mathrm{O}_{3}$ in contrasting light environments. Thus, the aim of this study was to evaluate (1) the growth and (2) the response of major enzymes of the catabolic pathways of sugar maple seedlings exposed to an extensive gradient of $\mathrm{O}_{3}$, from 0 to $300 \mathrm{~nL} . \mathrm{L}^{-1}$.

\section{MATERIAL AND METHODS}

\subsection{Growth of the seedlings and fumigation treatments}

One hundred and forty four sugar maple (Acer saccharum Marsh.) seedlings (two years old) were potted in early May of 1996 in 16 $\mathrm{L}$ pots (the soil came from a nearby maple stand: sandy loam with more than $10 \%$ organic matter). All the seedlings were from the Berthierville Nursery (Ministère des Ressources Naturelles, Québec, Canada). On May 29, after the development of the first flush of leaves, seedlings were equally distributed into 6 open-top chambers. The chambers used were similar to those described by Heagle et al. [19] (without a rain cap) and were located at the Centre de Recherche Acéricole du MAPAQ in Tingwick, approximately $200 \mathrm{~km}$ east of Montréal ( $45^{\circ} 54^{\prime} \mathrm{N}$ and $\left.71^{\circ} 57^{\prime} \mathrm{W}\right)$. Each chamber represented one of the $6 \mathrm{O}_{3}$ concentrations used in the gradient: (1) 0 nL.L ${ }^{-1} \mathrm{O}_{3}$; (2) 50 nL.L ${ }^{-1} \mathrm{O}_{3}$; (3) 100 nL.L. $\mathrm{O}_{3}^{-1}$; (4) 150 nL.L ${ }^{-1} \mathrm{O}_{3}$; (5) 200 nL.L ${ }^{-1}$ $\mathrm{O}_{3}$; (6) $300 \mathrm{~nL} \cdot \mathrm{L}^{-1} \mathrm{O}_{3}$. Measured mean $\mathrm{O}_{3}$ concentration in each chamber was $1 \pm 2.46 \mathrm{~nL} . \mathrm{L}^{-1} \mathrm{O}_{3}, 46 \pm 12 \mathrm{~nL} . \mathrm{L}^{-1} \mathrm{O}_{3}, 100 \pm 19$ nL.L $\mathrm{L}^{-1}$ $\mathrm{O}_{3}, 149 \pm 15$ nL.L ${ }^{-1} \mathrm{O}_{3}, 199 \pm 21$ nL.L ${ }^{-1} \mathrm{O}_{3}, 293 \pm 27$ nL.L $\mathrm{L}^{-1} \mathrm{O}_{3}$ respectively. Ozone treatments were administered from 6 a.m. to 8 p.m. for the entire growing season. The air entering the chambers was filtered with activated charcoal to remove pollutants prior to ozone enrichment. The ventilation rate was $\sim 85 \mathrm{~m}^{3} \cdot \mathrm{min}^{-1}$. $\mathrm{O}_{3}$ concentrations were measured hourly in the centre of the chamber. Hourly control and feedback adjustments of the $\mathrm{O}_{3}$ level were made using two UV-photometric $\mathrm{O}_{3}$ analysers (Monitor labs Inc., model 8810, Englewood, Colorado) linked to a datalogger (Campbell scientific Inc., model CR10, Edmonton, Alberta). Ozone was generated from dried ambient air using an OREC auto control ozonator (Ozone research \& Equipment Corporation, model 03SP38-ARW, Phoenix, AZ, USA) linked to the datalogger for feedback control. During the night, filtered air entered the chambers. Preliminary tests did not show any significant NOx increase in the out coming air. A more complete description of the chambers can be found in Renaud et al. [43].

To create contrasting light conditions, a neutral-density shade cloth was hung over half the area of each chamber. The irradiance was measured using a quantum sensor (Li-190SA, Li-COR, Lincoln, Neb.). At noon on a sunny day, the irradiance was $20 \%$ $\left(350 \mu \mathrm{mol} . \mathrm{m}^{-2} \cdot \mathrm{s}^{-1}\right)$ and $80 \%\left(1500 \mu \mathrm{mol} . \mathrm{m}^{-2} \cdot \mathrm{s}^{-1}\right)$ of the sunlight intensity measured in the field, for the low and high light treatments respectively.

\subsubsection{Morphological types of seedlings}

Sugar maple is often considered to be a fixed growth species, characterized by an entirely preformed shoot in the bud [25]. However, young seedlings, saplings, and young and vigorous branches of mature sugar maple may have an episodic growth pattern $[6,18,48]$

In this study, budbreak occurred in mid May prior to setting the seedlings into the chambers. The two seasonal patterns of shoot growth were observed among the seedlings. Two-third of the seedlings had a "truncated" shoot growth pattern similar to that described by Canham et al. [6] as a "cessation of aboveground growth early in the growing season". These seedlings with one leaf flush will be referred to as "truncated" seedlings. The other third of the seedlings had an "episodic" growth strategy [6]: once in the chambers, a second flush of leaves occurred between the end of June and the end of July. These seedlings with two flushes will be referred to as "episodic" seedlings. The first flush of leaves will be hereafter referred to as the preformed flush, consisting of preformed leaves and the second flush as neoformed flush consisting of neoformed leaves as described by Gregory [18].

\subsubsection{Harvesting of seedlings}

Seedlings were randomly harvested from each chamber and each light treatment on June 28 ( 31 days of $\mathrm{O}_{3}$ treatment), July 25 (57 days of $\mathrm{O}_{3}$ treatment) and August 22 ( 85 days of $\mathrm{O}_{3}$ treatment). Harvesting started at $13 \mathrm{~h}: 00$ and was completed within $4 \mathrm{~h}$.

At days 31 and 57, we collected two truncated seedlings per chamber per light treatment for a total of 24 seedlings. A sub-sample from a single leaf for each seedling was used for in vivo measurement of nitrate reductase (NR) activity and another sub-sample was oven-dried at $65{ }^{\circ} \mathrm{C}$ for 4 days and weighed to determine water content. The rest of the leaves were immediately set on dry ice and kept at $-80{ }^{\circ} \mathrm{C}$ for future enzymatic analysis.

At day 85, we collected two "truncated" seedlings per treatment per chamber and two episodic seedlings per treatment per chamber 
when available. The cumulative effects of $\mathrm{O}_{3}$ on the biomass were analyzed at this date. The two types of seedling were analyzed separately. Seedlings were immediately divided into roots, stems + petioles and leaves, which were weighed separately to estimate their fresh weight. The leaves and stems of the episodic seedlings were divided according to the different flushes. The projected leaf area of every leaf was measured using an area meter (Delta-T devices, Cambridge, England). Shoot length was measured in $\mathrm{cm}$ from root collar to terminal bud for truncated seedlings. For episodic seedlings, total shoot length was separated into two parts: from root collar to the last bud scar (previous year's growth + spring growth) and from bud scar to terminal bud (second flush of growth). The whole root, the whole stem of each flush and a sub-sample of preformed and neoformed leaves were oven-dried at $65^{\circ} \mathrm{C}$ for 4 days and weighed to determine water content. A sub-sample from a single leaf was used for the measurement of in vivo NR activity. The rest of the leaves were immediately set on dry ice and kept at $-80{ }^{\circ} \mathrm{C}$ for future enzymatic analysis.

\subsection{Evaluation of visible foliar injury}

Rapid visible foliar injury evaluations were done at day 57 and day 85 . A $20 \%$ scale $(\mathrm{O}-20 \% ; 21-40 \%$; 41-60\%; 61-80\%; 81$100 \%$ ) was used to evaluate the percentage of symptomatic leaves per seedling. We considered that a leaf was symptomatic if at least $2 \%$ of his area was injured.

\subsection{Enzymatic analysis}

\subsubsection{In vivo nitrate reductase assay}

At the field site, in parallel with the harvests and at all sampling dates, NR (E.C. 1.6.6.1.) activity was measured according to the method of Jaworski et al. [22] as modified by Truax et al. [53]. One hundred $\mathrm{mg}$ fresh weight of material from a single leaf was sampled from each flush of each seedling, cut into $2 \times 2 \mathrm{~mm}$ pieces and incubated in $5 \mathrm{~mL}$ of $100 \mathrm{mM}$ phosphate buffer ( $\mathrm{pH}$ 7.5) containing $40 \mathrm{mM} \mathrm{KNO}_{3}$ and 1.5\% 1-propanol. Each sample was vortexed for $2 \mathrm{~min}$ to help tissue infiltration by the incubation solution. The test tubes were sealed and incubated for $1 \mathrm{~h}$ at $30^{\circ} \mathrm{C}$. A blank containing one hundred $\mathrm{mg}$ fresh weight of leaf material without $\mathrm{KNO}_{3}$ was prepared for each sample. The reaction was stopped by immersing the tubes for $5 \mathrm{~min}$ in boiling water. The colorimetric determination of $\mathrm{NO}_{2}{ }^{-}$was done by mixing $0.25 \mathrm{~mL}$ of incubation medium with $0.25 \mathrm{~mL} 0.02 \% \mathrm{~N}-(1-\mathrm{Naphtyl})$ ethylenediamine and $0.25 \mathrm{~mL}$ of sulfanilamide. After $30 \mathrm{~min}$, the absorbance was read at $540 \mathrm{~nm}$.

\subsubsection{Enzyme extraction}

A sub-sample of frozen leaf tissue (200 mg FW) was ground to a fine powder in liquid nitrogen using a mortar and pestle. The leaf powder was extracted with $4 \mathrm{~mL}$ of cold $\left(4{ }^{\circ} \mathrm{C}\right) 0.1 \mathrm{M}$ Hepes-KOH buffer ( $\mathrm{pH} 7.5)$ containing $7 \%(\mathrm{w} / \mathrm{w})$ polyethylene glycol 20000, $2 \mathrm{mM}$ dithiothreitol, $5 \mathrm{mM} \mathrm{MgCl}_{2}, 5 \mathrm{mM}$ ethylene glycol-bis-(B-aminoethyl ether)-N,N,N',N'-tetra acetic acid, $10 \%$ (v/v) glycerol, $1 \mathrm{mM}$ phenylmethylsulfonyl fluoride, $9 \%(\mathrm{w} / \mathrm{v})$ insoluble polyvinylpyrrolidone 25000 . The homogenate was centrifuged at $8800 \times g$ for $10 \mathrm{~min}$ at $4{ }^{\circ} \mathrm{C}$. The supernatant was collected and used as a crude enzyme extract for the determination of total Rubisco, PEPC, G6PDH and GR activities.

\subsubsection{Enzyme assays}

Total ribulose 1,5-bisphosphate carboxylase oxygenase (Rubisco, E.C. 4.1.1.39) activity was measured spectrophotometrically at $340 \mathrm{~nm}$ in a coupled reaction at $30{ }^{\circ} \mathrm{C}$ according to the method of Lilley and Walker [31] as modified by Van Oosten et al. [56]. The assay medium consisted of $100 \mathrm{mM}$ bicine buffer ( $\mathrm{pH} 8$ ) containing $20 \mathrm{mM} \mathrm{MgCl} 2,25 \mathrm{mM} \mathrm{NaHCO} 3,3.5 \mathrm{mM}$ ATP, $0.25 \mathrm{mM}$ $\mathrm{NADH}, 3.5 \mathrm{mM}$ phospho-creatine, 80 nkat creatine phosphokinase (E.C. 2.7.3.2), 80 nkat 3-phosphoglycerate kinase (E.C. 2.7.2.3), 80 nkat glyceraldehyde 3-phosphate dehydrogenase (E.C. 1.2.1.12) and $30 \mu \mathrm{L}$ crude extract in a final volume of $600 \mu \mathrm{L}$. The mixture was pre-incubated for $15 \mathrm{~min}$ at $30{ }^{\circ} \mathrm{C}$ and $0.5 \mathrm{mM}$ ribulose 1,5 bisphosphate (RuBP) was added to start the reaction. A control without RuBP was prepared for each assay.

Phosphoenolpyruvate carboxylase (PEPC, E.C.4.1.1.31) activity was assayed by monitoring the decrease in absorbance at $340 \mathrm{~nm}$ in an assay system coupled with malate dehydrogenase (E.C. 1.1.1.37) at $30^{\circ} \mathrm{C}$. The assay medium was based on that of Tietz and Wild [50] and consisted of $112.5 \mathrm{mM}$ Tris-HCl buffer ( $\mathrm{pH} 8.5$ ) containing $5 \mathrm{mM}$ $\mathrm{MgCl}_{2}, 5 \mathrm{mM} \mathrm{NaHCO}_{3}, 0.2 \mathrm{mM}$ NADH, $2 \mathrm{mM}$ glucose 6-phosphate, $3 \mathrm{U} / \mathrm{mL}$ malate dehydrogenase and $30 \mu \mathrm{L}$ crude extract in a final volume of $600 \mu \mathrm{L}$. The reaction was initiated by adding $4.4 \mathrm{mM}$ phosphoenolpyruvate. The reference assay did not contain phosphoenolpyruvate.

Glucose 6-phosphate dehydrogenase (G6PDH, E.C. 1.11.49) activity was assayed at $30^{\circ} \mathrm{C}$ by monitoring the increase in absorbance at $340 \mathrm{~nm}$ using a modification of the method of Pitel and Cheliak [39]. The assay medium contained $50 \mathrm{mM}$ Hepes buffer ( $\mathrm{pH} 7.6$ ), $10 \mathrm{mM} \mathrm{MgCl} 2,300 \mu \mathrm{M} \mathrm{NADP}^{+}$and $30 \mu \mathrm{L}$ crude extract in a final volume of $600 \mu \mathrm{L}$. The reaction was initiated by adding $2 \mathrm{mM}$ glucose 6-phosphate. A control without glucose 6-phosphate was used for each assay.

Glutathione reductase (GR, E.C. 1.6.4.2) was assayed according to the procedure of Smith et al. [46]. The assay was performed at $34{ }^{\circ} \mathrm{C}$ in a final reaction volume of $1 \mathrm{~mL}$ containing $0.1 \mathrm{M} \mathrm{K}$ phosphate buffer ( $\mathrm{pH} 7.5), 0,5 \mathrm{mM}$ EDTA, 0,75 mM 5,5'-dithiobis (2-nitrobenzoic acid) (DTNB), $0.1 \mathrm{mM}$ NADPH and $25 \mu \mathrm{L}$ of enzyme extract. The reaction was initiated by the addition of $2 \mathrm{mM}$ GSSG. The formation of GSH was followed by the increase of $\mathrm{A}_{412}$ $\left(\varepsilon=7.2 \mathrm{mM}^{-1} \cdot \mathrm{cm}^{-1}\right)$. Soluble proteins in crude extracts were assayed using the Bio-Rad DC method. Enzymatic extracts were precipitated with $20 \%$ TCA for $10 \mathrm{~min}$ at $4{ }^{\circ} \mathrm{C}$ and centrifuged at $8800 \times g$ for $10 \mathrm{~min}$. The pellets were dissolved in $1 \mathrm{~N} \mathrm{NaOH}$. Enzyme activities were expressed in nkat $\mathrm{mg}^{-1}$ protein.

\subsection{Measurement of total phenolic compounds}

Leaf powder (120 mg DW from the oven-dried leaf sub-sample used for water content determination) was homogenized in $4 \mathrm{~mL}$ of $50 \%(\mathrm{v} / \mathrm{v})$ ethanol. The homogenate was incubated at $40{ }^{\circ} \mathrm{C}$ for $3 \mathrm{~h}$ and centrifuged at $8800 \times g$ for $10 \mathrm{~min}$ at room temperature. The supernatant was recovered and evaporated to dryness under a stream of nitrogen. The residue was resuspended in $3 \mathrm{~mL}$ distilled water and the phenol content was assayed colorimetrically using the FolinDenis reagent as described by Swain and Hillis [49]. Total phenolic compounds were determined by comparison with a standard curve generated with tannic acid as a reference. 
Table I. Summary of the regression analysis between diff $\mathrm{HL}_{-\mathrm{LL}}$ for the biomass of leaves, stems and roots $(\mathrm{g} \mathrm{DW})$, foliar surface $\left(\mathrm{cm}^{2}\right)$, specific leaf mass (SLM, g/Mm²), height $(\mathrm{cm})$, root/shoot ratio and $\mathrm{O}_{3}$ concentration (nL.L $\left.{ }^{-1}\right)$ after 85 days of treatment.

\begin{tabular}{|c|c|c|c|c|c|c|}
\hline \multicolumn{7}{|c|}{ Seedlings with one flush } \\
\hline & \multirow[t]{2}{*}{$\operatorname{Diff}_{\mathrm{HL}-\mathrm{LL}}$} & \multicolumn{2}{|c|}{ Parameter estimates $($ prob $>|t|)$} & \multirow[t]{2}{*}{$R^{2}$} & \multirow[t]{2}{*}{$\mathrm{I}^{\dagger}$} & \multirow[t]{2}{*}{$\mathrm{B}^{\dagger}$} \\
\hline & & Slope & Intercept & & & \\
\hline & Leaves & 0.070 & 0.470 & 0.58 & 0.4092 & -0.00728 \\
\hline & Foliar surface & 0.433 & 0.528 & 0.16 & 4.8251 & -0.03665 \\
\hline & SLM & 0.75 & 0.80 & 0.03 & -2.4840 & -0.01919 \\
\hline & Stems & 0.057 & 0.250 & 0.64 & 1.2956 & -0.01541 \\
\hline & Height & 0.185 & 0.532 & 0.39 & 5.6857 & -0.08140 \\
\hline & Roots & 0.050 & 0.134 & 0.66 & 3.5493 & -0.03160 \\
\hline & Root/shoot & 0.182 & 0.177 & 039 & 0.3404 & -0.00202 \\
\hline \multicolumn{7}{|c|}{ Seedlings with two flushes } \\
\hline & \multirow[t]{2}{*}{$\operatorname{diff}_{\mathrm{HL}-\mathrm{LL}}$} & \multicolumn{2}{|c|}{ Parameter estimates $($ prob $>|\mathrm{t}|)$} & \multirow[t]{2}{*}{$R^{2}$} & \multirow[t]{2}{*}{$\mathrm{I}^{\dagger}$} & \multirow[t]{2}{*}{$\mathrm{B}^{\dagger}$} \\
\hline & & Slope & Intercept & & & \\
\hline \multirow[t]{5}{*}{ First flush } & Leaves & 0.988 & 0.929 & $8.10^{-5}$ & -0.1364 & 0.00012 \\
\hline & Foliar surface & 0.692 & 0.818 & 0.06 & -2.4027 & 0.02314 \\
\hline & SLM & 0.317 & 0.441 & 0.32 & -1.465 & 1.0980 \\
\hline & Stems & 0.790 & 0.710 & 0.03 & -0.6696 & 0.00263 \\
\hline & Height & 0.774 & 0.858 & 0.03 & -2.3500 & 0.02100 \\
\hline \multirow[t]{7}{*}{ Second flush } & Leaves & 0.625 & 0.779 & 0.09 & 0.2074 & -0.00203 \\
\hline & Foliar surface & 0.394 & 0.357 & 0.25 & 8.8002 & -0.04462 \\
\hline & SLM & 0.627 & 0.878 & 0.09 & -4.4760 & 0.0802 \\
\hline & Stems & 0.863 & 0.707 & 0.01 & -0.1192 & -0.00030 \\
\hline & Height & 0.698 & 0.962 & 0.06 & -0.4625 & -0.02125 \\
\hline & Roots & 0.322 & 0.411 & 0.32 & 1.7093 & -0.01178 \\
\hline & Root/shoot & 0.688 & 0.727 & 0.06 & -0.1933 & -0.00125 \\
\hline
\end{tabular}

${ }^{\dagger} \operatorname{Diff}_{\mathrm{HL}-\mathrm{LL}}=\mathrm{I}+\mathrm{B}\left(\mathrm{O}_{3}\right)$, where $\mathrm{I}$ is the intercept, $\mathrm{B}$ is the slope and $\mathrm{O}_{3}$ is the $\mathrm{O}_{3}$ concentration $\left(\mathrm{nL} \cdot \mathrm{L}^{-1}\right)$.

\subsection{Statistical analyses}

We established the influence of the light regimes on the responses of the different variables tested (biomass parameters, Rubisco, G6PDH, PEPC, GR and NR activities, soluble protein content, total phenolic compounds) to the ozone gradient. We calculated the difference between the value of a variable under high light and low light; the difference was reported as "diff $\mathrm{HL}_{\mathrm{LL}}$ " at each concentration of the $\mathrm{O}_{3}$ gradient and at each harvest date. We then completed a series of regression analyses using $\mathrm{O}_{3}$ as an independent variable and "diff ${ }_{\mathrm{HL}-\mathrm{LL}}$ " as a dependent variable for each measured parameters.

These analyses showed that the responses of these variables to the ozone gradient were not different for the two light regimes, except in 2 cases (phenol content and NR activity). In most cases, the slope and the intercept of the regressions were not different from zero (Tabs. I, II and III). Therefore, we pooled the data from both light intensities for the analysis of the effect of the $\mathrm{O}_{3}$ gradient, except for the phenol content of the truncated seedlings at day 57, which was significantly different under low and high light (Tab. II) and the NR activity of the first flush of the episodic seedlings at day 85, where there was an interaction between $\mathrm{O}_{3}$ and light (Tab. III).

We chose the regression approach to assess the quantitative relationships between our measured variables and the $\mathrm{O}_{3}$ gradient. With six levels of ozone, regression is the most powerful way of analyzing the data [47]. A series of linear regressions using the six different $\mathrm{O}_{3}$ concentrations as the independent variable and the pooled data (biomass parameters, Rubisco, G6PDH, PEPC, GR and NR activities, soluble protein content, total phenolic compounds) as the dependent variable were completed at each harvest day. On two occasions data were not pooled, for the phenol content at day 57 and the NR activity of the first flush of the episodic seedlings at day 85 . On day 85 , a second-order regression was used to examine the response of G6PDH and PEPC activities, because these data responses were not linear. All regression analyses were performed using the statistical software JMP 3 (SAS Institute Inc.) The level of significance was set at 0.05 .

\section{RESULTS}

\subsection{The effects of light and ozone on biomass}

Light treatments had no effect on biomass parameters (Figs. 1 and 2). Biomass accumulation of leaves, stems, roots and foliar surface area of the two morphologically different groups of seedlings, shoot length of the second flush of episodic seedlings decreased with increasing $\mathrm{O}_{3}$ (Figs. 1 
Table II. Summary of the regression analysis between diff $_{\mathrm{HL}-\mathrm{LL}}$ for soluble proteins, Rubisco, GR, G6PDH, PEPC, NR, phenol content and $\mathrm{O}_{3}$ concentration for seedlings with one flush at each harvest day.

\begin{tabular}{|c|c|c|c|c|c|c|}
\hline \multirow[t]{2}{*}{$\operatorname{Diff}_{H L-L L}$} & \multirow[t]{2}{*}{ Day of harvest } & \multicolumn{2}{|c|}{ Parameter estimates $(\operatorname{prob}>|\mathrm{t}|)$} & \multirow[t]{2}{*}{$R^{2}$} & \multirow[t]{2}{*}{$\mathrm{I}^{\dagger}$} & \multirow[t]{2}{*}{$\mathrm{B}^{\dagger}$} \\
\hline & & Slope & Intercept & & & \\
\hline \multirow[t]{3}{*}{ Proteins } & 31 & 0.257 & 0.507 & 0.30 & 0.8673 & 0.00948 \\
\hline & 57 & 0.247 & 0.213 & 0.31 & -3.0503 & 0.01682 \\
\hline & 85 & 0.925 & 0.804 & 0.002 & 0.7933 & 0.00181 \\
\hline \multirow[t]{3}{*}{ Rubisco } & 31 & 0.240 & 0.395 & 0.32 & -0.3178 & 0.00278 \\
\hline & 57 & 0.697 & 0.143 & 0.04 & 1.1231 & 0.00156 \\
\hline & 85 & 0.307 & 0.087 & 0.25 & 1.6619 & -0.00521 \\
\hline \multirow[t]{3}{*}{ GR } & 31 & 0.790 & 0.680 & 0.02 & -0.0315 & 0.00012 \\
\hline & 57 & 0.606 & 0.148 & 0.07 & 0.1069 & -0.00020 \\
\hline & 85 & 0.959 & 0.602 & 0.001 & 0.0380 & -0.00002 \\
\hline \multirow[t]{3}{*}{ G6PDH } & 31 & 0.432 & 0.444 & 0.16 & -0.0976 & -0.00061 \\
\hline & 57 & 0.267 & 0.817 & 0.29 & -0.0362 & 0.00114 \\
\hline & 85 & 0.403 & 0.984 & 0.18 & -0.0024 & 0.00060 \\
\hline \multirow[t]{3}{*}{ PEPC } & 31 & 0.578 & 0.809 & 0.08 & 0.0710 & -0.00100 \\
\hline & 57 & 0.123 & 0.099 & 0.48 & 0.3182 & -0.00175 \\
\hline & 85 & 0.957 & 0.493 & 0.001 & 0.0921 & -0.0004 \\
\hline \multirow[t]{3}{*}{ NR } & 31 & 0.401 & 0.996 & 0.18 & 0.0034 & 0.00360 \\
\hline & 57 & 0.107 & 0.088 & 0.52 & 0.8901 & 0.00494 \\
\hline & 85 & 0.626 & 0.682 & 0.06 & 0.0430 & -0.00031 \\
\hline \multirow[t]{3}{*}{ Phenols } & 31 & 0.847 & 0.362 & 0.014 & 30.8707 & 0.03716 \\
\hline & 57 & 0.263 & 0.025 & 0.30 & 36.9461 & -0.08331 \\
\hline & 85 & 0.770 & 0.682 & 0.05 & -31.7380 & 0.11430 \\
\hline
\end{tabular}

${ }^{\dagger} \operatorname{Diff}_{\mathrm{HL}-\mathrm{LL}}=\mathrm{I}+\mathrm{B}\left(\mathrm{O}_{3}\right)$, where $\mathrm{I}$ is the intercept, $\mathrm{B}$ is the slope and $\mathrm{O}_{3}$ is the $\mathrm{O}_{3}$ concentration (nL. $\mathrm{L}^{-1}$ ).

Table III. Summary of the regression analysis between diff $\mathrm{HL}-\mathrm{LL}_{\text {for }}$ soluble proteins, Rubisco, GR, G6PDH, PEPC, NR, phenol content and $\mathrm{O}_{3}$ concentration for the heterophyllous seedlings after 85 days.

\begin{tabular}{|c|c|c|c|c|c|c|}
\hline \multirow[t]{2}{*}{$\operatorname{Diff}_{\mathrm{HL}-\mathrm{LL}}$} & \multirow[t]{2}{*}{ Flush } & \multicolumn{2}{|c|}{ Parameter estimates $($ prob $>|t|)$} & \multirow[t]{2}{*}{$R^{2}$} & \multirow[t]{2}{*}{$\mathrm{I}^{\dagger}$} & \multirow[t]{2}{*}{$\mathrm{B}^{\dagger}$} \\
\hline & & Slope & Intercept & & & \\
\hline \multirow[t]{2}{*}{ Proteins } & First & 0.173 & 0.175 & 0.51 & 6.7360 & -0.03758 \\
\hline & Second & 0.776 & 0.794 & 0.03 & 1.0680 & -0.00646 \\
\hline \multirow[t]{2}{*}{ Rubisco } & First & 0.286 & 0.666 & 0.36 & 0.3482 & -0.00524 \\
\hline & Second & 0.404 & 0.455 & 0.24 & 0.9658 & -0.00608 \\
\hline \multirow[t]{2}{*}{ GR } & First & 0.289 & 0.970 & 0.35 & -0.0042 & 0.00075 \\
\hline & Second & 0.280 & 0.293 & 0.52 & 0.2680 & -0.00206 \\
\hline \multirow[t]{2}{*}{ G6PDH } & First & 0.328 & 0.652 & 0.31 & -0.1620 & 0.00210 \\
\hline & Second & 0.840 & 0.997 & 0.01 & 0.0012 & 0.00039 \\
\hline \multirow[t]{2}{*}{ PEPC } & First & 0.929 & 0.850 & 0.01 & -0.0753 & -0.00019 \\
\hline & Second & 0.544 & 0.464 & 0.13 & -0.1491 & -0.00067 \\
\hline \multirow[t]{2}{*}{ NR } & First & 0.020 & 0.015 & 0.86 & 0.1113 & 0.00050 \\
\hline & Second & 0.060 & 0.061 & 0.88 & 0.3081 & 0.00110 \\
\hline \multirow[t]{2}{*}{ Phenols } & First & 0.726 & 0.472 & 0.07 & 30.7590 & -0.07544 \\
\hline & Second & 0.487 & 0.716 & 0.26 & 15.7376 & -0.16955 \\
\hline
\end{tabular}

${ }^{\dagger} \operatorname{Diff}_{\mathrm{HL}-\mathrm{LL}}=\mathrm{I}+\mathrm{B}\left(\mathrm{O}_{3}\right)$, where $\mathrm{I}$ is the intercept, $\mathrm{B}$ is the slope and $\mathrm{O}_{3}$ is the $\mathrm{O}_{3}$ concentration (nL. $\left.\mathrm{L}^{-1}\right)$. 

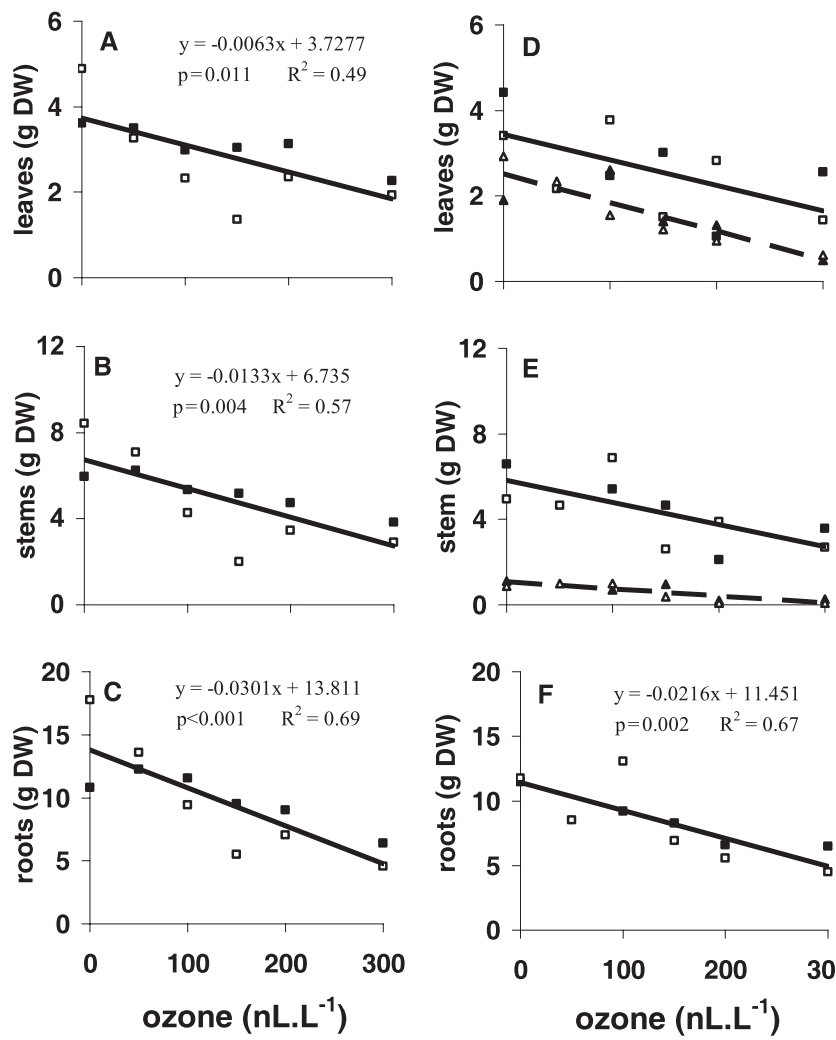

truncated seedlings

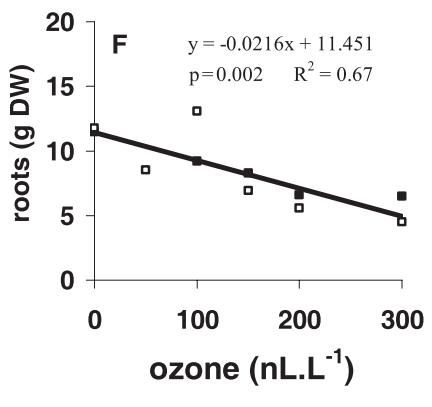

episodic seedlings

Figure 1. Biomass of leaves, stems, roots (g DW) of the truncated (A, $\mathrm{B}, \mathrm{C})$ and episodic (D, E, F) seedlings after 85 days under increasing $\mathrm{O}_{3}$ concentrations (data from first flush grown under low light ( $(\boldsymbol{)})$ and high light ( $\square$ ), — regression line; data from second flush grown under low light $(\boldsymbol{\Delta})$ and high light $(\Delta),--$ regression line). D: first flush: $y=$ $-0.006 x+3.44, R^{2}=0.36, p=0.05$; second flush: $y=-0.0067 x+$ 2.5142, $R^{2}=0.77, p<0.001$. E: first flush: $y=-0.0104 x+5.8252$, $R^{2}=0.47, p=0.02$; second flush: $y=-0.0033 x+1.0701, R^{2}=0.71$, $p=0.001$.

and 2). The specific leaf mass (SLM) of both morphological types of seedling was not influenced by $\mathrm{O}_{3}$ (Fig. 2).

The truncated seedlings allocated a large proportion of their biomass to the root system (with a root/shoot ratio above one) whereas the episodic seedlings, which allocated biomass for the development of the neoformed flush, had a root/shoot ratio less than one. Irradiance levels did not modify the root/shoot ratio of either group of seedlings (data not shown), nor did increasing $\mathrm{O}_{3}$ level: both shoot growth and root growth decreased with increasing $\mathrm{O}_{3}$, leading to a constant root/shoot ratio (Fig. 2).

\subsection{Visible leaf injury}

The different types of leaf injury usually associated with $\mathrm{O}_{3}$ were observed mostly on the first flush. Stipples appeared
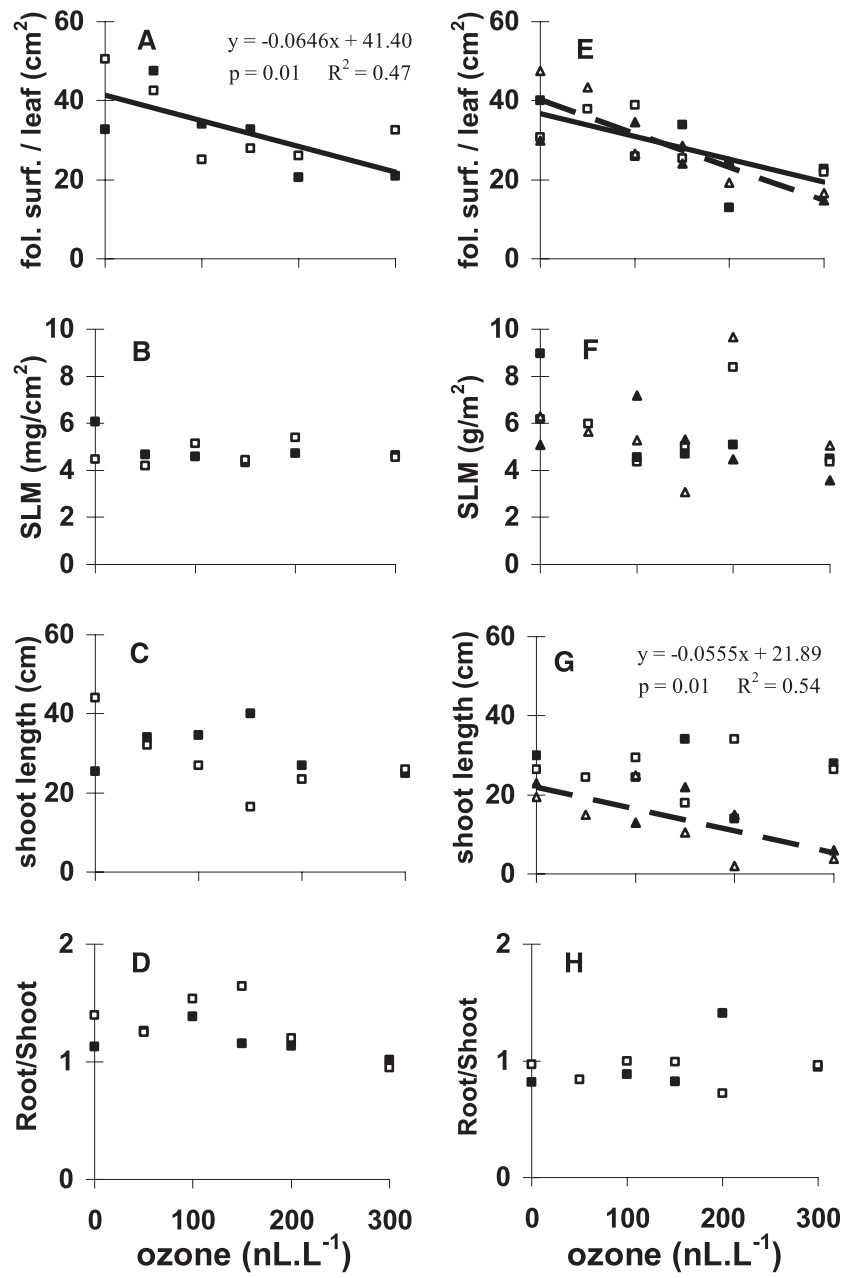

truncated seedlings

episodic seedlings

Figure 2. Foliar surface per leaf $\left(\mathrm{cm}^{2}\right)$, specific leaf mass per leaf $\left(\mathrm{SLM}, \mathrm{g} / \mathrm{m}^{2}\right)$, shoot length $(\mathrm{cm})$, root/shoot ratio of the truncated (A, B, C, D) and episodic seedlings (E, F, G, H) after 85 days of treatment under increasing $\mathrm{O}_{3}$ concentrations (data from first flush grown under low light (ם) and high light ( $\square$ ), — regression line; data from second flush grown under low light $(\Delta)$ and high light $(\Delta),--$ regression line). E: first flush: $y=-0.0572 x+36.667, R^{2}=0.49, p=0.01$; second flush: $y=-0.0852 x+40.18, R^{2}=0.73, p=0.0007$.

uniformly on the upper leaf surface and have a purple-brown coloration. Some brown bifacial necrotic spots were observed. At day 57, no foliar injury was observed on seedlings exposed at 0 and $50 \mathrm{~nL} . \mathrm{L}^{-1} \mathrm{O}_{3}$ (data not shown). Half of the seedlings exposed at $200 \mathrm{~nL} . \mathrm{L}^{-1} \mathrm{O}_{3}$ and $85 \%$ of the seedlings exposed at $300 \mathrm{~nL} . \mathrm{L}^{-1} \mathrm{O}_{3}$ have more than $80 \%$ of symptomatic leaves (i.e. leaves with at least $2 \%$ of leaf area injured). At day 85 , we still did not observe foliar injury on seedlings exposed to 0 and $50 \mathrm{~nL} . \mathrm{L}^{-1} \mathrm{O}_{3}$. More than $70 \%$ of the seedlings exposed at $200 \mathrm{~nL} . \mathrm{L}^{-1} \mathrm{O}_{3}$ and $95 \%$ of the seedlings exposed at $300 \mathrm{~nL} . \mathrm{L}^{-1}$ $\mathrm{O}_{3}$ have more than $80 \%$ of symptomatic leaves. 


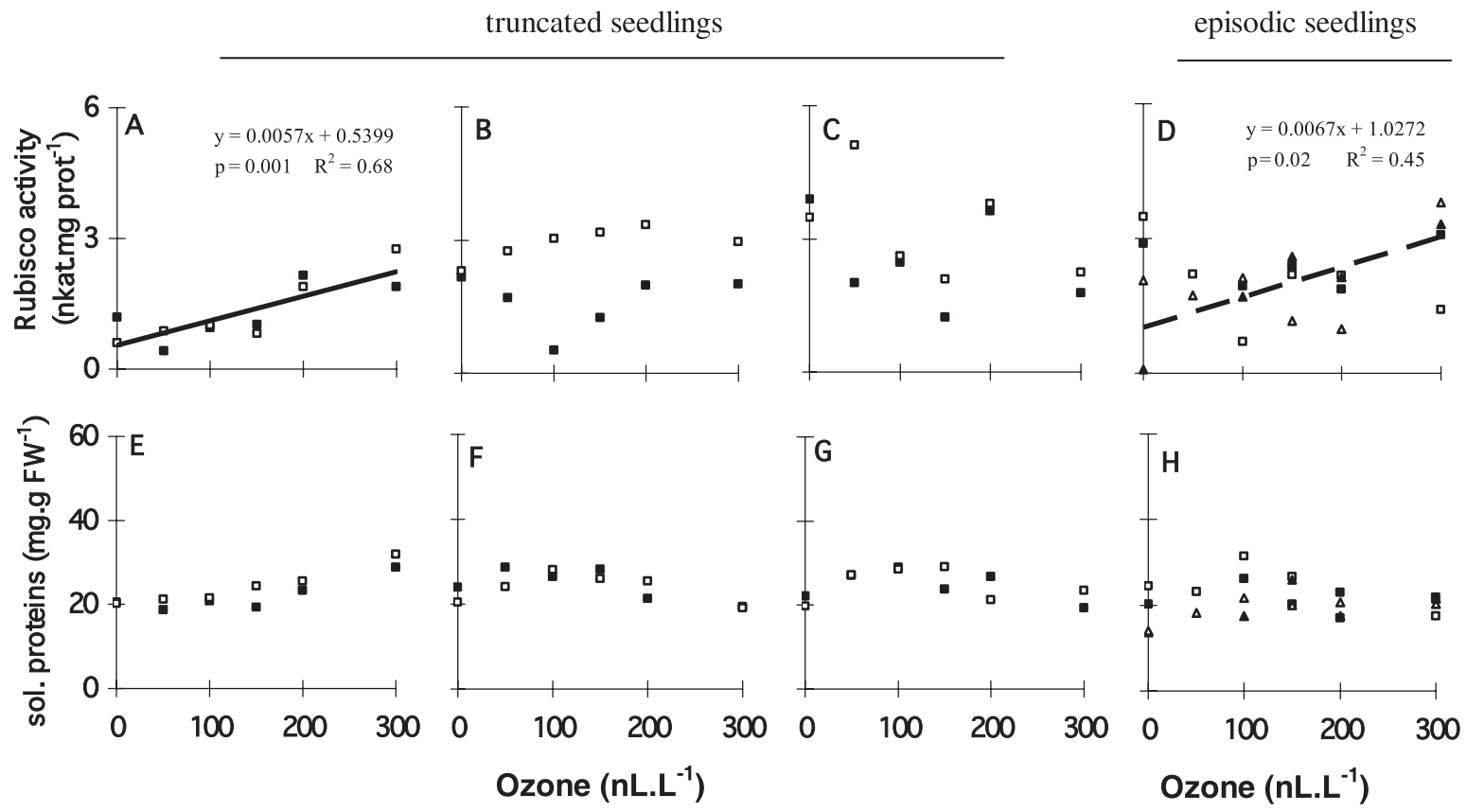

Figure 3. Rubisco activity (nkat.mg prot ${ }^{-1}$ ) and soluble protein content (mg.gFW ${ }^{-1}$ ) for the truncated seedlings after 31 days (A, E), 57 days $(B, F)$ and 85 days $(C, G)$ and the episodic seedlings $(D, H)$ under increasing $\mathrm{O}_{3}$ concentrations (data from first flush grown under low light $(\square)$

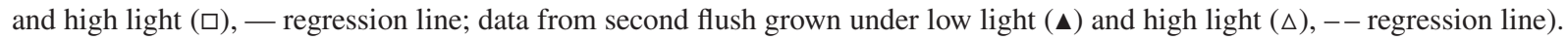
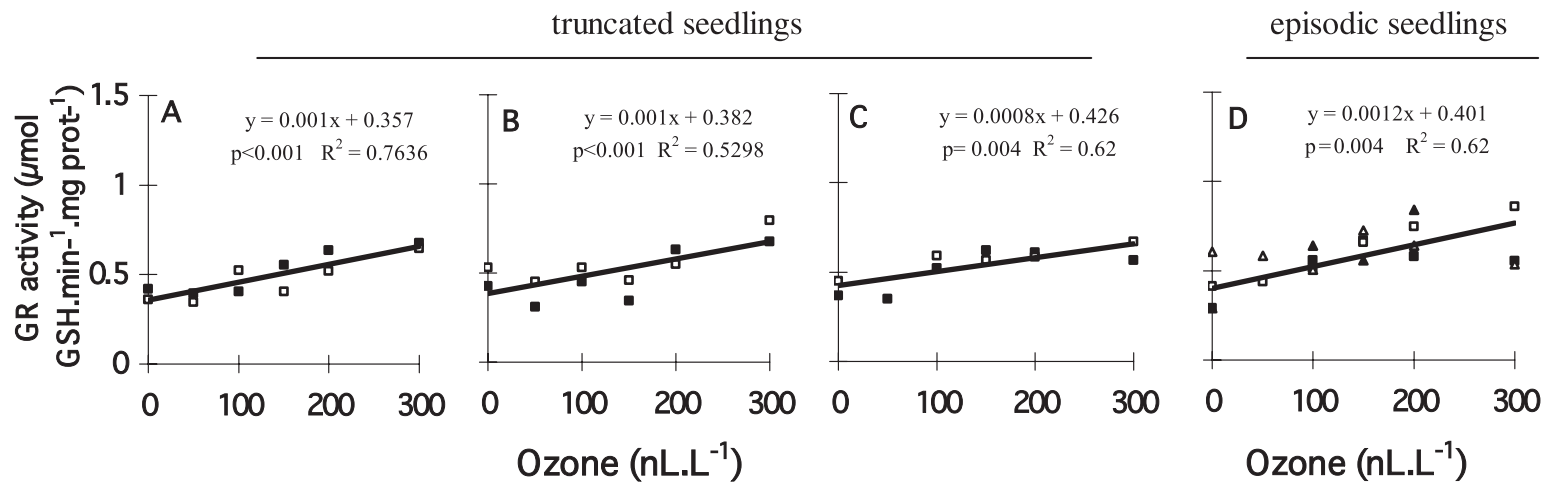

Figure 4. GR activity ( $\mu \mathrm{mol} \mathrm{GSH} \cdot \mathrm{min}^{-1} \cdot \mathrm{mg} \mathrm{prot}^{-1}$ ) for the truncated seedlings after 31 days (A), 57 days (B) and 85 days (C) and the episodic seedlings (D) under increasing $\mathrm{O}_{3}$ concentrations (data from first flush grown under low light $(\boldsymbol{\square})$ and high light ( $\square$ ), — regression line; data from second flush grown under low light $(\boldsymbol{\Lambda})$ and high light $(\Delta),-$ regression line).

\subsection{Effect of light and ozone on enzymatic responses}

When the results were expressed on a foliar surface basis or on a protein basis the same variation in the response to the treatment was observed. The Rubisco activity of the truncated seedlings was increased by exposure to $\mathrm{O}_{3}$ on day 31 but was not affected by $\mathrm{O}_{3}$ on days 57 and 85 (Figs. 3A-3C). After 85 days of treatment, the Rubisco activity of the neoformed flush increased with increasing $\mathrm{O}_{3}$ (Fig. 3D). The soluble protein content was constant during the whole growing season and was not affected by $\mathrm{O}_{3}$ (Figs. 3E-3H).

The $\mathrm{O}_{3}$ treatment led to a significant stimulation in the GR activity of preformed leaves of both seedling types throughout the growing season (Figs. 4A-4D).
G6PDH activity was highly stimulated by increased $\mathrm{O}_{3}$ levels at each harvest day (Figs. 5A-5D). However, with time, the level of activity decreased under the higher concentrations of $\mathrm{O}_{3}$ : after 85 days, non-linear relationship was significant and the activity of G6PDH in the neoformed flush of the episodic seedlings decreased when $\mathrm{O}_{3}$ concentration exceeded 150 nL.L ${ }^{-1}$ (Fig. 5D).

Anaplerotic fixation of $\mathrm{CO}_{2}$ by PEPC increased in response to $\mathrm{O}_{3}$ in both groups of seedlings (Figs. $5 \mathrm{E}-5 \mathrm{H}$ ) during the growing season. The level of activity decreased in the neoformed flush of the episodic seedlings when the $\mathrm{O}_{3}$ concentration exceeded 150 nL.L ${ }^{-1}$ (Fig. 5H). After 85 days the Rubisco/PEPC ratio in the truncated seedlings grown in the absence of $\mathrm{O}_{3}$ was 5. At $300 \mathrm{~nL} \cdot \mathrm{L}^{-1} \mathrm{O}_{3}$ in the 


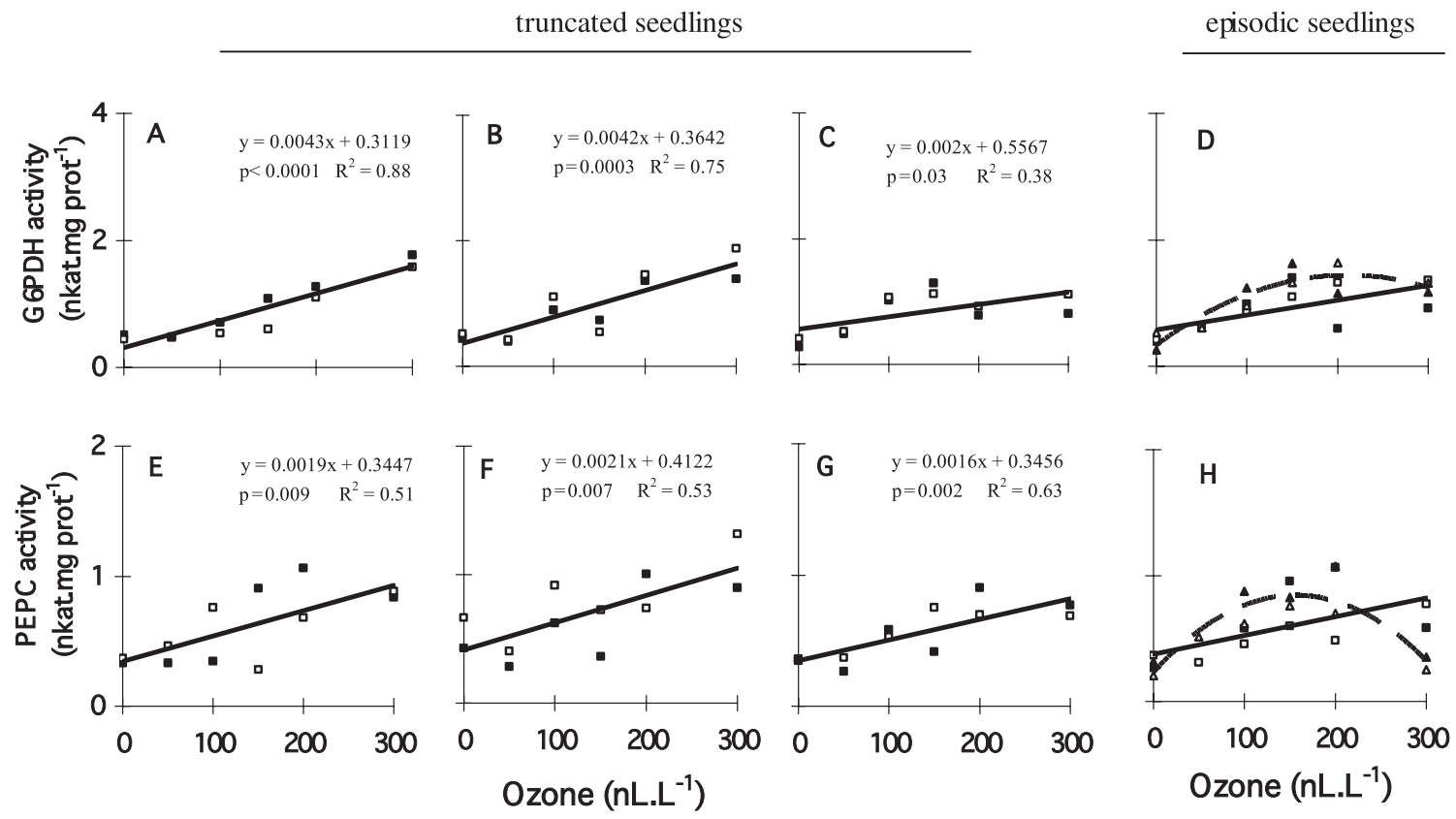

Figure 5. G6PDH activity (nkat.mg prot $^{-1}$ ) and PEPC activity (nkat.mg $\operatorname{prot}^{-1}$ ) for the truncated seedlings after 31 days (A, E), 57 days (B, F) and 85 days $(C, G)$ and the episodic seedlings $(D, H)$ under increasing $\mathrm{O}_{3}$ concentrations (data from first flush grown under low light $(\square)$ and high light $(\square)$, — regression line; data from second flush grown under low light ( $\Delta)$ and high light $(\Delta),--$ regression line). D: first flush: $y=0.0023 x+0.5751, p=0.026, R^{2}=0.43$; second flush: $y=-2.10^{-5} x^{2}+0.0105 x+0.3356, p<0.001, R^{2}=0.83$. H: first flush: $y=0.00145 x+0.377, p=0.017, R^{2}=0.29$; second flush: $y=-3.10^{-5} x^{2}+0.0078 x+0.2312, p=0.001, R^{2}=0.82$.

truncated seedlings, as PEPC activity increased two-fold over the seedlings grown in absence of $\mathrm{O}_{3}$ and Rubisco activity was not modified, the Rubisco/PEPC ratio decreased to 2.5.

The NR activity of the seedlings grown in the absence of $\mathrm{O}_{3}$ decreased more than two-fold during the growing season. In the truncated seedlings there was no change in the NR activity under $\mathrm{O}_{3}$ (Figs. 6A-6C). On day 85, the first flush of the episodic seedlings has a higher NR activity under high light than under low light, whereas the effect of $\mathrm{O}_{3}$ was not significant (Fig. 6D, note the distribution of the white and black squares). In the second flush, no effect of light was observed but $\mathrm{NR}$ activity decreased with increasing $\mathrm{O}_{3}$ (Fig. 6D).

On day 57, the total phenolic content was higher under high irradiance than under low irradiance (Fig. 6F, note the distribution of the white and black squares). $\mathrm{O}_{3}$ had no effect on the phenol content under high irradiance or low irradiance (Fig. 6F). On day 85, the total phenol content decreased in both flushes of leaves in response to $\mathrm{O}_{3}$ (Fig. $6 \mathrm{H}$ ).

\section{DISCUSSION}

The growth rate of the seedlings was similar under both light environments used in our experiment. Sugar maple is a shade tolerant species [3] and its assimilation rate is maximal at low levels of irradiance. The carbon gain of sugar maple has been shown to increase more between $1 \%$ and $10 \%$ of full sunlight than between 10 and 100\% [11]. The light environments in our experiment were comparable to the levels found in large gaps (low irradiance treatment) and in plantations (high irradiance treatment). We conclude that the assimilation rates of the seedlings were not limited by light availability, resulting in a similar total carbon gain and a similar growth rate for seedlings in both light treatments. Leaf morphology, structure and thickness are known to differ with increasing irradiance levels [2,51]. However, in our study, specific leaf mass values were similar at both irradiance levels. This indicates that all the leaves had a similar morphology. The SLM values are in the range of those found by Fortin and Mauffette [13] for the sun leaves of sugar maple, which confirmed that both light environments represent sunny conditions for the growth of sugar maple seedlings.

In the absence of $\mathrm{O}_{3}$, episodic seedlings had a higher growth than truncated seedlings. However, these seedlings were not able to sustain episodic growth under high $\mathrm{O}_{3}$, thus, after 85 days at 300 nL.L ${ }^{-1}$, both types of seedlings had a similar total biomass. Increasing oxidative stress limited new carbon skeletons production, less of which were then available for the development of new sink tissues. The root/shoot ratio was not affected by increasing $\mathrm{O}_{3}$ in truncated nor episodic seedlings. The seedlings showed a reduced accumulation of biomass in below and above ground tissues in the same proportion so that root/shoot ratios remained constant across the $\mathrm{O}_{3}$ gradient. This may be considered to be a conservative strategy which enhances the survivorship of the seedlings of slowgrowing species [5].

Some enzymatic stimulation was also involved in this conservative strategy. The Rubisco activity was generally not 


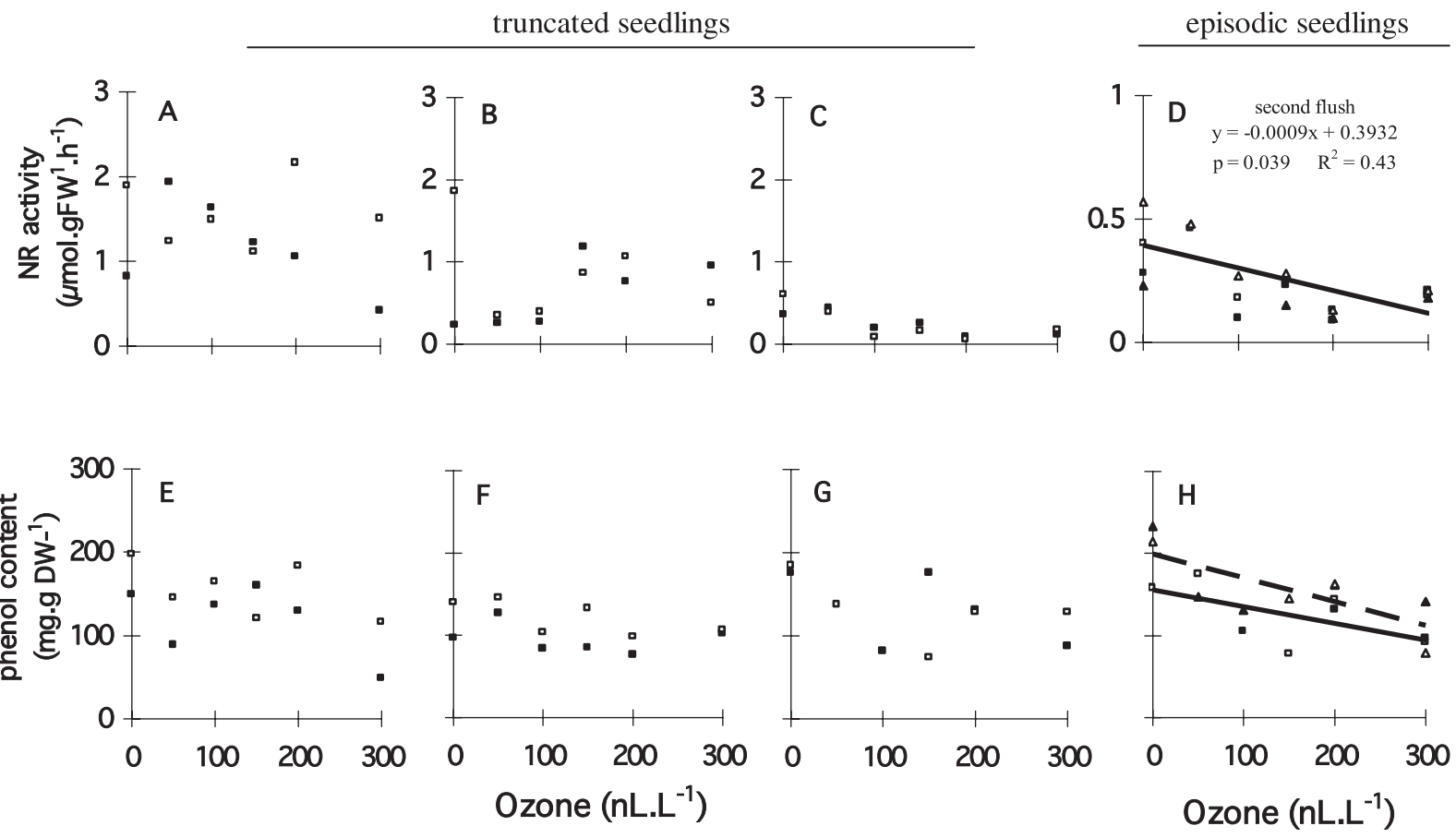

Figure 6. $\mathrm{NR}$ activity $\left(\mu \mathrm{mol} \mathrm{NO} \mathrm{NO}_{2} \cdot \mathrm{FW}^{-1} \cdot \mathrm{h}^{-1}\right.$ ) and phenol content (mg.g DW ${ }^{-1}$ ) for the truncated seedlings after 31 days (A, E), 57 days $(B, F)$ and 85 days $(C, G)$ and the episodic seedlings $(\mathrm{D}, \mathrm{H})$ under increasing $\mathrm{O}_{3}$ concentrations (data from first flush grown under low light $(\boldsymbol{\square})$ and high light ( $\square),-$ regression line; data from second flush grown under low light $(\Delta)$ and high light $(\Delta),--$ regression line). H: first flush: $y=-0.2041 x+155.85, p=0.04, R^{2}=0.46$; second flush: $y=-0.2903 x+199.19, p=0.02, R^{2}=0.55$.

affected by high $\mathrm{O}_{3}$ concentrations and actually increased at the end of June and at the end of August in the younger leaves of the episodic flush under high $\mathrm{O}_{3}$. This stimulation of $\mathrm{CO}_{2}$ fixation by Rubisco in young foliar tissues may be a transient response to oxidative stress. A similar transient response was observed in a previous study where 45 day-old sugar maple seedlings were exposed to $200 \mathrm{~nL} . \mathrm{L}^{-1} \mathrm{O}_{3}$ in phytotronic chambers during 61 days [16]. However, in some other species decreased Rubisco activity and quantity is a more constant response to $\mathrm{O}_{3}[12,33,38]$.

The scavenging of toxic $\mathrm{O}_{3}$ derivatives is in part achieved by the ascorbate-glutathione detoxification cycle [14]. GR is one of the enzymes of this cycle. In the present study, GR activity increased two-fold in sugar maple seedlings in response to increasing $\mathrm{O}_{3}$ stress. This enzyme ensures a high level of GSH regeneration and thus an efficient functioning of the detoxification cycle by keeping ascorbate in a functional reduced state. We measured a significant increase in the G6PDH activity with increasing $\mathrm{O}_{3}$. G6PDH is a key enzyme of the oxidative pentose phosphate pathway, which may oxidize 5 to $20 \%$ of cellular glucose (the other 80 to $95 \%$ is oxidized by glycolysis). Stimulation of this enzyme allows an enhanced NADPH production. GR may consume 25 to $50 \%$ of the total NADPH produced during the day [4] and may use the NADPH produced by G6PDH. In the neoformed flush of the episodic seedlings, stimulation of G6PDH activity was not maintained until the end of the season (day 85) when $\mathrm{O}_{3}$ exceeded 150 nL.L ${ }^{-1}$. Therefore, NADPH production should also decrease with the reduction of G6PDH activity. How- ever, GR activity was maintained at a high level suggesting that the enzyme used NADPH produced by the photochemical reactions of photosynthesis. At high $\mathrm{O}_{3}$ concentrations the decrease in G6PDH may be due to a reduced availability of its substrate, glucose 6-phosphate, which in turn may be due to a larger allocation of the glyceraldehyde 3-P to glycolysis at the expense of starch synthesis and the pentose-phosphate pathway.

Stimulation of PEPC activity was observed as $\mathrm{O}_{3}$ concentration increased. In the cytosol, PEPC produces the oxaloacetate needed for de novo synthesis of amino acids, which are used for protein synthesis [29]. Under oxidative stress, proteins may be degraded by $\mathrm{O}_{3}$ and its by-products [28]. Thus, a large proportion of newly synthesized proteins are allocated to the repair processes [45]. The increased PEPC activity observed in our seedlings presumably supplied the repair processes via the anaplerotic pathway [45]. However, after 85 days, this stimulation was not maintained in the neoformed flush of the episodic seedlings when $\mathrm{O}_{3}$ exceeded 150 nL.L ${ }^{-1}$. This suggested a lower capacity for the production of aminoand organic acids and, consequently, a lower input to the repair processes at the end of the season.

The total phenol content is reported to increase in response to $\mathrm{O}_{3}[8,32]$ and phenolic compounds such as the precursors of lignin are known to be implicated in the repair processes of injured leaves [23]. However, phenol content of truncated seedlings remained unchanged with increasing $\mathrm{O}_{3}$ and even decreased with increasing $\mathrm{O}_{3}$ for episodic seedlings. Large progression of foliar symptoms observed at the end of the 
season suggested that less precursors and less energy was allocated to repair of injured foliar tissues. As PEPC transformed PEP to OAA and as PEPC activity increased with increasing $\mathrm{O}_{3}$, the PEP availability may have decreased. Thus the amount of PEP, which is a precursor of phenols, may be less available for the synthesis of phenolic compounds. Seedlings may partition PEP between the replenishment of the tricarboxylic acid cycle and the shikimate pathway. The allocation of PEP to the tricarboxylic acid cycle may have increased with increasing $\mathrm{O}_{3}$ whereas its allocation to the shikimate pathway may have decreased.

The NR activity was decreased by more than two-fold during the growing season in the absence of ozone. During expansion and maturation of the leaves, $\mathrm{N}$ assimilation is mainly under the control of NR. After maturation, $\mathrm{N}$ assimilation decreases and recycled $\mathrm{N}$ from photorespiration or protein degradation constitutes the major source of $\mathrm{N}$ in the plant [27]. The high level of NR activity on days 31 and 57, together with the stimulation of the PEPC by $\mathrm{O}_{3}$, may support the production of amino- and organic acids directed to repair processes. However, after 85 days, the NR activity in the seedlings was lower and decreased with increasing $\mathrm{O}_{3}$. At that time in the season and with increasing oxidative stress, $\mathrm{NH}_{3}$ may have been provided from photorespiration to allow the regeneration of amino acids derived from carbon skeletons provided by the PEPC, which still had a high activity. Only a few studies have measured the response of photorespiration to oxidative stress and contradictory results have been observed. Dizengremel and Pétrini [9] observed an increase in the photorespiration pathway in plants under pollutant stress. However, Manderscheid et al. [34] measured a decrease in glycolate oxidase activity (a peroxisomal enzyme of the photorespiratory pathway) in Pinus taeda needles exposed to air pollution.

As a shade tolerant, slow growing species [3], sugar maple has a low assimilation rate, leading to a compromise between maximizing aboveground growth and developing below ground growth to enhance the survivorship of seedlings [5,17]. Under oxidative stress, the stimulation of the enzymes implicated in energy, reducing power and carbon skeleton production in response to $\mathrm{O}_{3}$ may be a part of the species-related survivalist strategy of growth for sugar maple, which allowed seedlings to tolerate the high $\mathrm{O}_{3}$ levels of this experiment.

However, under high $\mathrm{O}_{3}$, growth of neoformed flush of the episodic seedlings is reduced and foliar injuries of the seedlings are important. Moreover, PEPC and G6PDH activities were depressed after 85 days in the neoformed flush when exposed to more than $150 \mathrm{~nL} . \mathrm{L}^{-1} \mathrm{O}_{3}$. The cumulative oxidative stress was too large and possibly exceeded the capacity for detoxification and repair of the neoformed flush. The defensive capacity of these neoformed flush seems to collapse at the end of the season. As previously explained, this may lead to a decreased production of reducing power and carbon skeletons resulting in a less efficient repair and detoxification processes. The presence of a second flush did not confer an advantage to the episodic seedlings for detoxification or repair. Thus, the potentially more vigorous episodic seedlings did not tolerate the oxidative stress more efficiently than the truncated seedlings during one growing season.
Acknowledgements: We are grateful to M. Cartier, C. Pitre and R. Veilleux for assistance in the field and to Dr. François Lorenzetti for statistical advice. We thank J. Leblanc for the phenols content measurements. This work was supported in part by a grant from the "Ministère des Relations internationales du Québec" and "Ministère français des Affaires étrangères" (coopération France-Québec) $\mathrm{n}^{\circ}$ PVP 10-1 and in part by a grant from the Natural Sciences and Engineering Research Council of Canada, and by the Centre de Recherche Acericole (MAPAQ).

\section{REFERENCES}

[1] Ashton P.M.S., Yoon H.S., Thadani R., Berlyn G.P., Seedling leaf structure of New England maples (Acer) in relation to light environment, For. Sci. 45 (1999) 512-519.

[2] Bäck J., Vanderklein D.W., Topa M.A., Effects of elevated ozone on $\mathrm{CO}_{2}$ uptake and leaf structure in sugar maple under two light environments, Plant Cell Environ. 22 (1999) 137-147.

[3] Baker F.S., A revised tolerance table, J. Forest. 47 (1949) 179-181.

[4] Burke J.J., Hatfield J.L., Plant morphological and biochemical responses to field water deficits. III: Effect of foliage temperature on the potential activity of glutathione reductase, Plant Physiol. 85 (1987) 100-103.

[5] Canham C.D., Berkowitz A.R., Kelly G.M., Ollinger S.V. Schnurr J., Biomass allocation and multiple resource limitation in tree seedlings, Can. J. For. Res. 26 (1996) 1521-1530.

[6] Canham C.D., Kobe R.K., Latty E.R., Chazdon R.L., Interspecific and intraspecific variation in tree seedlings survival: effects of allocation to roots versus carbohydrate reserves, Oecologia 121 (1999) $1-11$.

[7] Carlson R.W., Reduction in the photosynthetic rate of Acer, Quercus and Fraxinus species caused by sulphur dioxide and ozone, Environ. Pollut. 18 (1979) 159-170.

[8] Chappelka A.H., Chevone B.I., Tree responses to ozone, in: Lefohn A.S. (Ed.), Surface level ozone exposures and their effects on vegetation, Lewis Publishers Inc., 1991, pp. 271-324.

[9] Dizengremel P., Pétrini M., Effects of air pollutants on the pathway of carbohydrate breakdown, in: Alscher R.G., Wellburn A.R. (Eds.), Plant responses to the gaseous environment, Chapman \& Hall, 1994, pp. 255-278.

[10] Dizengremel P., Sasek T.W., Brown K.J., Richardson C.J., Ozoneinduced changes in primary carbon metabolism enzymes of loblolly pine needles, J. Plant Physiol. 144 (1994) 300-306.

[11] Ellsworth D.S., Reich P.B., Leaf mass per area, nitrogen content and photosynthetic carbon gain in Acer saccharum seedlings in contrasting forest light environments, Funct. Ecol. 6 (1992) 423-435.

[12] Fontaine V., Pelloux J., Podor M., Afif D., Gérant D., Grieu P., Dizengremel P., Carbon fixation in Pinus halepensis submitted to ozone. Opposite response of ribulose-1,5-bisphosphate carboxylase/oxygenase and phosphoenolpyruvate carboxylase, Physiol. Plant. 105 (1999) 187-192.

[13] Fortin M., Mauffette Y., The suitability of leaves from different canopy layers for a generalist herbivore (Lepidoptera: Lasiocampidae) foraging on sugar maple, Can. J. For. Res. 32 (2002) 379-389.

[14] Foyer C.H., Halliwell B., The presence of glutathione and glutathione reductase in chloroplasts: a proposed role in ascorbic acid metabolism, Planta 133 (1976) 21-25.

[15] Fuentes J.D., Dann T.F., Ground-level ozone in eastern Canada: seasonal variations, trends, and occurences of high concentrations, J. Air Waste Manage, Assoc. 44 (1994) 1019-1026.

[16] Gaucher C., Costanzo N., Afif D., Mauffette Y., Chevrier N., Dizengremel P., The impact of elevated ozone and carbon dioxide on young Acer saccharum (Marsh.) seedlings, Physiol. Plant. 117 (2003) 392-402. 
[17] Gaucher C., Gougeon S., Mauffette Y., Messier C., Seasonal variation in biomass and carbohydrate partitioning of understory sugar maple (Acer saccharum) and yellow birch (Betula alleghaniensis) seedlings, Tree Physiol. 25 (2005) 93-100.

[18] Gregory R.A., Annual cycle of shoot development in sugar maple, Can. J. For. Res. 10 (1980) 316-326.

[19] Heagle S.A., Philbeck R.B., Rogers H.H., Letchworth M.B., Dispensing and monitoring ozone in open-top field chambers for plant effect studies, Phytopathology 69 (1989) 15-20.

[20] Hogsett W.E., Weber J.E., Tingey D., Herstrom A., Lee E.H., Laurence J.A., An approach for caracterizing tropospheric ozone risk to forests, Environ. Manage. 21 (1997) 105-120.

[21] Isaksen I.S.A., Hov Ø., Calculation of trends in the tropospheric concentration of $\mathrm{O}_{3}, \mathrm{OH}, \mathrm{CO}, \mathrm{CH}_{4}$ and $\mathrm{NO}_{\mathrm{x}}$, Tellus 39B (1987) 271-285.

[22] Jaworski E.G., Nitrate reductase assay in intact plant tissue, Biochem. Biophys. Res. Co. 43 (1971) 1274-1279.

[23] Jones C.G., Coleman J.S., Plant stress and insect herbivory: toward an integrated perspective, in: Mooney H.A., Winner W.E., Pell E.J. (Eds.), Response of plants to multiple stresses, Academic Press, 1991, pp. 249-274.

[24] Kickert R.N., Krupa S.V., Forest responses to tropospheric ozone and global climate change: an analysis, Environ. Pollut. 68 (1990) 26-65.

[25] Kramer P.J., Kozlowski T.T., Physiology of woody plants, Academic Press, Orlando, FL, 1979, 811 p.

[26] Kress L.W., Skelly J.M., Response of several eastern forest tree species to chronic doses of ozone and nitrogen dioxide, Plant Dis. 66 (1982) 1149-1152.

[27] Lam H.M., Coschigano K.T., Oliveira I.C., Melo-Oliveira R., Coruzzi G.M., The molecular-genetics of nitrogen assimilation into amino acids in higher plants, Ann. Rev. Plant Physiol. 47 (1996) 569-93.

[28] Larson R.A., Plant defences against oxidative stress, Arch. Insect Biochem. 29 (1995) 175-186.

[29] Latzko E., Kelly G.J., The many-faceted function of phosphoenolpyruvate carboxylase in $\mathrm{C}_{3}$ plants, Physiol. Veg. 21 (1983) 805815.

[30] Laurence J.A., Kohut R.J., Amundson R.G., Weinstein D.A., Mac Lean D.C., Response of sugar maple to multiple year exposures to ozone and simulated acidic precipitation, Environ. Pollut. 92 (1996) 119-126.

[31] Lilley R.C., Walker D.A., An improved spectrophotometric assay for ribulose bisphosphate carboxylase, Biochem. Biophys. Acta 358 (1974) 226-229.

[32] Luethy-Krause B., Pfenninger I., Landolt W., Effects of ozone on organic acids in needles of Norway spruce and Scots pine, Trees 41 (1990) 198-204.

[33] Lütz C., Anegg S., Gérant D., Alaoui-Sossé B., Gérard J. Dizengremel P., Beech trees exposed to high $\mathrm{CO}_{2}$ and to simulated summer ozone levels: effects on photosynthesis, chloroplast components and leaf enzyme activity, Physiol. Plant. 109 (2000) 252-259.

[34] Manderscheid R., Jâger H.-J., Kress L.W., Effects of ozone on foliar nitrogen metabolism of Pinus taeda L. and implications for carbohydrate metabolism, New Phytol. 121 (1992) 623-633.

[35] Noble R., Jensen K.F., Ruff B.S., Loats K., Response of Acer saccharum to elevated carbon dioxide and ozone, Ohio J. Sci. 92 (1992) 60-62.

[36] Nakano Y., Asada K., Spinach chloroplasts scavenge hydrogen peroxide on illumination, Plant Cell Physiol. 21 (1980) 1295-1307.

[37] Noctor G., Foyer C.H., Ascorbate and glutathione: keeping active oxygen under control, Ann. Rev. Plant Physiol, Plant Mol. Biol. 49 (1998) 249-279.

[38] Pell E.J., Eckardt N., Glick R.E., Biochemical and molecular basis for impairment of photosynthetic potential, Photosynth. Res. 39 (1994) 453-462.
[39] Pitel J.A., Cheliak W.M., Effectiveness of protective agents for increasing the activity of five enzymes from vegetative tissues of white spruce, Can. J. Bot. 64 (1985) 39-43.

[40] Prather M., Gauss M., Berntsen T., Isaksen I., Sundet J., Bey I., Brasseur G., Dentener F., Derwent R., Stevenson D., Grenfell L., Hauglustaine D., Horowitz L., Jacob D., Mickley L., Lawrence M., von Kuhlmann R., Muller J.-F., Pitari G., Rogers H., Johnson M., Pyle J., Law K., van Weele M., Wild O., Fresh air in the 21st century? Geophys. Res. Lett. 30 (2003).

[41] Rebbeck J., Chronic ozone effects on three northeastern hardwood species: growth and biomass, Can. J. For. Res. 26 (1996) 1788-1798.

[42] Rebbeck J., Loats K.V., Ozone effects on seedlings sugar maple (Acer saccharum) and yellow-poplar (Liriodendron tulipifera) gas exchange, Can. J. For. Res. 27 (1997) 1595-1605.

[43] Renaud J.P., Allard G., Mauffette Y., Effects of ozone on yield, growth, and root starch concentrations of two alfafa (Medicago sativa L.) cultivars, Environ. Pollut. 95 (1997) 273-281.

[44] Robichaux A., Analyse des niveaux d'ozone troposphérique en milieu forestier, réseau REMPAFAQ (1989-1991). Direction de l'environnement forestier, service du suivi environnemental, Québec, 1994, p. 84.

[45] Sehmer L., Fontaine V., Antoni F., Dizengremel P., Effects of ozone and elevated atmospheric carbon dioxide on carbohydrate metabolism of spruce needles, Catabolic and detoxification pathways, Physiol. Plant. 102 (1998) 605-611.

[46] Smith I.K., Vierheller T.L., Thorne C.A., Assay of glutathion reductase in crude tissue homogenates using 5,5'-dithiobis (2nitrobenzoic acid), Ann. Biochem. 175 (1988) 408-413.

[47] Sokal R., Rohlf J., Biometry: The Principles and Practice of Statistics in Biological Research, Freeman and Co., New-York, 1995, pp. 451-554.

[48] Steingraeber D.A., Heterophylly and neoformation of leaves in sugar maple (Acer saccharum), Am. J. Bot. 69 (1982) 1277-1282.

[49] Swain T., Hillis W.E., The phenolic constituents of Prunus domestica. The quantitative analyses of phenolic constituents, J. Sci. Food Agric. 10 (1959) 63-68.

[50] Tietz S., Wild A., Investigations on the phosphoenolpyruvate carboxylase activity of spruce needles relative to the occurrence of novel forest decline, J. Plant Physiol. 137 (1991) 327-331.

[51] Tjoelker M.G., Volin J.C., Oleksyn J., Reich P.B., Interaction of ozone pollution and light effects on photoynthesis in a forest canopy experiment, Plant Cell Environ. 18 (1995) 895-905.

[52] Topa M.A., Vanderklein D.W., Corbin A., Effects of elevated ozone and low light on diurnal and seasonal carbon gain in sugar maple, Plant Cell Environ. 24 (2001) 663-677.

[53] Truax B., Gagnon D., Chevrier N., Nitrate assimilation of raspberry and pin cherry in a recent clearcut, Can. J. Bot. 72 (1994) 13431348.

[54] Tucker G.F., Lassoie J.P., Fahey T.J., Crown architecture of standgrown sugar maple (Acer saccharum Marsh.) in the Adirondack Mountains, Tree Physiol. 13 (1993) 297-310.

[55] Turner S., Problématique de l'ozone troposphérique au Québec et dans la région de Montréal, Environnement Canada (1995).

[56] Van Oosten J.J., Afif D., Dizengremel P., Long-term effects of a $\mathrm{CO}_{2}$ enriched atmosphere on enzymes of the primary carbon metabolism of spruce trees, Plant Physiol. Biochem. 30 (1992) 541547.

[57] Von Althen F.W., Hardwood plantation establishment on former farmland in southern Ontario, Pap. Pres. at the 21st Semaine des sciences for., Univ. Laval, Québec, 1990, p. 18.

[58] Wieser G., Hecke K., Tausz M., Häberle K-H., Grams T.E.E., Matyssek R., The influence of microclimate and tree age on the defense capacity of European beech (Fagus sylvatica L.) against oxidative stress, Ann. For. Sci. 60 (2003) 131-135.

[59] Yawney H.W., Planting sugar maple, in: Sugar maple research: sap production, processing and marketing of maple syrup, USDA, For Serv., Northeastern For. Exp. Stn., Broomall (PA), Gen. Tech. Rep. NE-72 (1982) 53-60. 